\title{
The Illusion of Balance: Women in ICT Working Full-Time and Still Having a Feeling of Opting Out
}

\author{
Gilda Seddighi ${ }^{1 *}$, Hilde G. Corneliussen ${ }^{2}$
}

Published: September 1, 2021

\begin{abstract}
Women - mothers in particular - working as ICT experts in research, development, and innovation are under double pressure: they work within both a male-dominated profession, and a greedy, 24/7 work style that continues to produce an image of the ideal worker according to the male norm of less childcare responsibility. This study explores how women working as ICT experts in research, development, and innovation in Norway's gender egalitarian culture negotiate work alongside family responsibilities. We discuss which factors affect women's experiences of combining ICT work and family, building our analysis on 22 interviews conducted with women ICT experts in research, development, and innovation in Norway during 2017-2018. Our study illustrates that insufficient public childcare and work-life balance solutions cause women to feel like they are 'opting out', even when working full-time. This suggests that some of the main structures of working life continue to work as barriers to women's career opportunities. Indeed, while some women narrate their encounters with such structures along the lines of traditional gendered patterns of work and family, we also found the same structures being gendered in new ways.
\end{abstract}

Keywords: work-life balance, research and innovation, ICT work, career, motherhood

\section{INTRODUCTION}

In Norway, most fields of information, communication, and technology (ICT) work are still male-dominated. In this paper, we ask: How do women in fields of ICT research, development, and innovation in Norway's gender egalitarian culture negotiate the contradictory values of work and family? As digitalisation changes the landscape of ICT work and increases the need for ICT expertise in non-technical fields, education, training, and upskilling are crucial for ICT research, development, and innovation. However, unequal gendered divisions of labour in care and household responsibilities remain barriers to career development in ICT research, development, and innovation's greedy work cultures (Quesenberry et al., 2006; Bailey and Riley, 2018; EIGE, 2020). Indeed, it is increasingly challenging to reconcile time constraints between work and family (Lewis et al., 2007) as the pace of work intensifies (Mauno et al., 2019). As women take on a greater share of care responsibilities (EIGE, 2018; Seierstad and Kirton, 2015), it is a matter, not only of making time for work and family, but also navigating gendered work cultures and norms, such as around parenthood (Bø et al., 2008; Ellingsæter, 2006; Hakim, 2006). While women are often associated with 'mommy tracks' (Quesenberry et al., 2006) or the 'family schema', men are often associated with a 'work schema' (Hakim, 2006). These associations create expectations of how men and women reconcile work and family responsibilities, leaving women who do not integrate into the greedy, typically male work style at risk of not being perceived as 'true professionals' (Padavic et al., 2019: 64; Singstad, 2011).

The context for our study is Norway, recognised for its high degree of gender equality and progressive welfare regime that supports women's participation in working life (Seierstad and Kirton, 2015). Recent directives include family-oriented measures that not only support mothers returning to work, but also fathers taking parental leave (Kitterød and Halrynjo, 2019). Although women make up 47 percent of the workforce (Statistics Norway, 2018), traditional gender norms that locate women as the primary family caregiver are still prevalent (Seierstad and Kirton, 2015). This is reflected in the number of women who work part-time: currently, 37 percent of employed women work only part-time, as compared to 13 percent of employed men (Statistics Norway, 2018). While policies have 
helped women return to work earlier, they have not been beneficial to women's career development (Kitterød and Halrynjo, 2019).

Women make up only one in four of those studying and working in ICT in Norway (Simonsen and Corneliussen, 2020; Statistics Norway, 2018; Samordna opptak, 2018). A recent European study found that women in ICT experience more flexible working conditions and a smaller pay gap than in other fields, but also work longer hours, with a lower proportion having childcare responsibilities (EIGE, 2018). In addition to this, fewer women in ICT work part-time, as compared to other occupations (Simonsen and Corneliussen, 2020). These factors indicate a double pressure on women, as they try to perform care work, as well as fit into a style of work that favours men as ideal workers (Singstad, 2011; Watts, 2009; Acker, 1995). This specific context highlights the need to conduct research on how women working as ICT experts in research, development, and innovation reconcile family and work responsibilities, while pursuing their career.

Drawing on the theory of 're-doing gender' (Hirschauer, 2001; West and Zimmerman, 1987), this article delves into how women in ICT research, development, and innovation re-do gender through their negotiation of work, family, and responsibilities. We ask which factors affect women's experiences of combining ICT work and family. In addition, considering how the work-life balance discourse is widespread across many countries (Rottenberg, 2018), including Norway (Sørensen, 2017), we also look at women's negotiation of ICT work and family responsibilities in the context of the work-life balance discourse, aiming to contribute to its critiques.

Our study includes interviews with 22 women working full-time in ICT research, development and innovation in Norway, whose accounts we introduce using a narrative analysis approach (Freeman, 2015). Our findings suggest that some of the main structures of working life, such as practices that create expectations favouring men, continue to challenge women's career opportunities. Some of our interviewees spoke of their encounters with these structures, along the lines of traditional gendered patterns of work and family, employing the discourse of choice. However, we also found that the above-mentioned structures are being re-gendered, yet, this still does not necessarily challenge work cultures that discriminate against women more than men. Most importantly, our analysis reveals the need to take a critical view of the work-life balance discourse, as even the term itself lays responsibility for creating 'balance' at the feet of the individual (Gregory and Milner, 2009). Taking such a view is important to policymakers' understanding of the economic and social structures that enable or restrict women's opportunities for careers in male-dominated fields, such as ICT.

We begin with a literature review, before presenting this study's theoretical and methodological framework. Following this, the article turns to an analysis of our data: women's accounts of how they reconcile work and family responsibilities. Using a narrative analysis approach the analysis is divided by two main narratives: the feeling of opting out while working full-time, and support for working more than full-time.

\section{GENDERED STRUCTURES OF WORK AND NORMS OF CARE FOR WOMEN IN ICT}

Despite family-friendly employment policies, women struggle to reconcile work and care responsibilities in social democratic welfare states, such as Norway (Kitterød and Halrynjo, 2019). While there is little difference in career development among dual-career childless couples in Norway, there remains a notable difference between mothers and fathers (Halrynjo and Lyng, 2010). The reconciliation of work and care responsibilities is even more difficult in male-dominated fields, (Watts, 2006) such as ICT, where the need to continuously upskill is a precondition for a successful career (EIGE, 2018:3). Flexible parental leave (Rudlende and Bryghaug, 2017), a higher uptake of paternal quota leave (Gram, 2019), and the extension of kindergarten to children aged one and two have aided women's faster return to work (Johnsen and Løken, 2016). However, these policies do not seem to have had an impact on women's career development (Kitterød and Halrynjo, 2019).

Work-life balance - referring to solving the dilemmas of intertwining institutional and non-work times and spaces (Felstead et al., 2002) - has become a dominant discourse in many societies (Rottenberng, 2018), including Norway (Sørensen, 2017), over the past few decades. Indeed, the discourse is at the forefront of policies aiming to increase women's workforce participation and improve conditions for them to pursue careers (OECD, 2004). These policies focus on workers' autonomy, individuals' control over their time, and flexibility in work arrangements (Fleetwood, 2007; Lewis et al., 2007), implying that this balance relies on individuals' choices (Gregory and Milner, 2009). However, such framing neglects 'the recognition of privileges and inequalities between groupings of people and individuals' (Niemistö et al. 2019: 506), and thus, does not challenge well-established structures of gendered work cultures (Chung and Van der Lippe, 2018). In this section, we focus on the structures covered up by the work-life balance discourse; namely, the gendered culture of work, and norms of care in international literature, Norway, and the ICT field.

Work cultures, especially in male-dominated fields, imagine the 'ideal worker' (Acker, 1990) as one who prioritises work over care responsibilities (Williams, 2000), something men typically appear to do more often than women (Singstad, 2011). As many have shown, the pace and requirements of work have intensified (Mauno et al., 
2019) over the past decades, creating a work culture marked by greed (Hakim, 2006), and the expectation of constant availability or a 24/7 work style (Padavic et al., 2019). Research on working life in Norway has also shown that employees in some sectors experience a greedy or boundaryless work culture where standard, full-time work is not enough (Brandth and Kvande, 2005; Nilsen and Skarsbø, 2009). Greedy work culture is caused by changes such as intensification of work where employers have extraordinary demands and expectations from their employees' attitude, behaviour and time (Franzway, 2001; Peetz, 2006). These expectations are even more prevalent in male-dominated fields such as ICT (Watts, 2006). As several studies have suggested, women in ICT work more than women in many other occupations (EIGE, 2018; Watts, 2009). Watts' (2009) study of women in engineering shows that women working full-time adopt work styles that include long hours, as they perceive this as necessary to being accepted in the workplace. A $24 / 7$ work culture - i.e., employees' increased availability due to such technologies as email and mobile phones - has blurred the boundaries between work time and private time, workplace and private space, and intensified the challenges of negotiating work and family time, for women more so than men (Zerwas, 2019).

The gender norms of care responsibilities are another well-established structure hidden within the work-life balance discourse. This is often looked at as a matter of choice; for example, Hakim's suggestion that men and women tend to choose different career paths, as women are drawn more towards jobs that 'can be fitted around family life' (2006: 285). From a British perspective, Hakim argues that family-friendly policies do not solve gender equality, rather they increase inequalities by allowing women to reduce their work time. Consequently, women struggle to compete against full-time workers with 'a momentum, knowledge, fitness and experience that can never be achieved by a part time worker' (Hakim, 2006: 282).

Adding a layer of normative evaluation to her model, Sørensen (2017) identifies three subject positions describing women's actions using the vocabulary of choice in the Norwegian media: 'the part-time working, good mother' opting out of work; 'the exceptional career mother' who aims to have it all, both children and a career; and 'the failing mother', who also aims to have it all, but faces accusations of failing at motherhood. Sørensen (2017: 310) argues that invoking the vocabulary of choice here not only covers up power structures, as McRobbie (2009) shows, but it also produces differences and inequalities.

Literature on intensive parenting gives new context to studies investigating women's choice in relation to work and care. Ideal parenting, especially mothering, has increasingly been drawn from the ideal of intense commitment to parental requirements and the mother role over the past decades (Hays, 1996; Stefansen and Aarseth, 2011). Pedersen and Egeland's (2020) study of Norwegian parents' everyday life confirms that so-called intensive parenting is practiced by Norwegian parents, especially highly educated and middle-class families, and that the ideal parenting style in Norway relies on equally shared parenting responsibilities. Mothers administrate care responsibilities and function as the primary caregiver, but it is the parents' working hours that influence how workcare conflicts are solved. Pedersen and Egeland explain further that parents with flexible working hours have a greater capacity to solve work-care conflicts regardless of gender. However, this is a privilege one earns, often through extended higher education. According to a study by EIGE,

ICT jobs actually offer favourable working conditions for both men and women. Working hours are often more flexible and employees have more autonomy in adjusting them to their needs. (EIGE, 2018: 3)

However, flexible working conditions can also cause more intensified working patterns (Ellingsæter, 2002; Richardson and Bennetts, 2007), as this situation leaves the responsibility for work-life balance to the individual (Håpnes and Rasmussen, 2007). Pedersen and Egeland (2020) show that parents with flexible working hours who must solve work-care conflicts during work hours catch up with their work in the late evenings or over weekends. For mothers with flexible working hours, this becomes another burden, in addition to being the primary caregiver. As women often take more care responsibilities, the ICT industry's flexibility might be both a pressure on and barrier to women's career advancement in the sector (Consalvo, 2008), even though flexible hours may be a privilege that women in other sectors do not have.

The focus on employees' autonomy and flexible working time (or place) shows the privileges that women in ICT fields have, but also hides the potential double pressure they face. This is because the responsibility for dealing with work-life balance is left to the individual and remains a task of the private sphere. In the context of the dominant work-life balance discourse, complete balance being the ideal, this study sheds light on gendered structures and privileges that contribute to the way in which women in ICT negotiate the relationship between work and family demands. 


\section{RE-DOING GENDER: NEGOTIATIONS WITHIN TWO-TRACK PARENTHOOD}

This article is part of a larger project looking at women's careers in ICT research, development, and innovation through the lens of emphasising the social construction of gender and technology (Cockburn, 1992; Corneliussen, 2011; Sørensen et al., 2011). Feminist technology studies have shown that, across the Western world, cultures and stereotypes tend to associate men with ICT work more so than women (Corneliussen, 2014; Misa, 2010; Wajcman, 2004). To address how women negotiate the relationship between work and family roles and responsibilities, this article employs the concepts of negotiation and re-doing gender. 'Doing gender' is a central concept in research on gender and work, as it seeks to understand how gender is practiced and stabilised (Gherardi, 1994), as well as how these practices contribute to producing hierarchies and inequalities (Nentwich and Kelan, 2014) in the work context. 'Doing gender' is defined by West and Zimmerman (1987: 125) as:

a complex of socially guided perceptual, interactional, and micropolitical activities that cast particular pursuits as expressions of masculine and feminine 'natures'.

In this article, doing gender refers to the practices drawn from gender norms used to reconcile work and life in the Norwegian context.

Although women's high workforce participation in Norway has established the idea of the dual-earner household (Melby and Carlsson Wetterberg, 2009; Singstad, 2011), a male-earner norm still prevails (Ellingsæter and Leira, 2006). Work practices create expectations favouring men (Acker, 1990) as the 'ideal worker' who prioritises work over care responsibilities (Williams, 2000). Despite policies aimed at increasing men's participation in care responsibilities (Kitterød and Rønsen, 2012), the combination of the dual-earner household and this 'ideal worker' has created a pattern of 'two-track parenthood': one track for mothers, often taking long parental leave and part-time work, and another for men emphasising work rather than family, regardless of whether they have children (Bø et al., 2008; Ellingsæter, 2006). The two-track parenthood model is the dominant gender norm regulating work-life balance in Norway, guiding gendered practices in the process.

A work-life balance implicitly taken as a happy solution to the reconciliation of work and family responsibilities has become an ideal 'enfolded into mainstream common sense' (Rottenberg, 2018:8). In this regard, the concept of negotiation refers to women's attempts to overcome the competing values and practices of work and family life while imagining a 'balanced' work-family life - i.e., 'having it all'. Focusing on how full-time working women with care responsibilities reconcile work and family, we look closer at how negotiation in relation to a two-track parenthood model is practiced. In this sense, negotiation refers to the practices of 're-doing' gender norms associated with the two-track parenthood model, however, not by changing the model itself but by changing women's and men's positions in the model. Different from 'undoing' gender norms that results in these norms losing their importance in social interactions (cf. Hirschauer, 2001), the concept of re-doing refers to social practices enacted in new ways, but still with reference to conventional gender norms and values (Kelan, 2010).

\section{METHODOLOGY}

\section{Interviews with women working in ICT research, development and innovation}

This article builds upon interviews with women working as ICT experts in research, development, and innovation in Western Norway. We recruited women through organisations working with regional innovation, ICT development, research, and funding agencies, as well as public and private companies. The selection criteria included: higher education, the minimum being an undergraduate degree, and diversity, in terms of women working as ICT experts in different sectors and industries, as we recognise that digitalisation is changing the landscape of ICT work.

The data presented here is part of a larger dataset of 28 interviews we conducted with women ICT experts in 2017-2018. Twenty-two of the interviews analysed here were with women who also had childcare responsibilities. One had an undergraduate degree, seven had PhDs, and the rest had postgraduate taught degrees. The interviewees were between 37 and 59 years old (average 45). 14 were born in Norway and eight were immigrants born in counties in North and West Europe, East and South Asia and East Africa. These women immigrated to Norway for higher education or work. No other information about informants' social backgrounds was gathered. In Norway higher education and work reduce social differences. All interviewees had higher education and a job that is considered to have high income. The women had between one and four children, some women having children of different ages and with different fathers. Thus, our participants represented a variety of heterosexual family constellations.

Seven interviewees had their first degree in ICT and two had a second degree in ICT, after first obtaining a degree in a non-technical discipline. These women work as ICT experts in management, design, programming, research, and implementation of new technology. Thirteen interviewees acquired ICT competence by combining 
an ICT education with a non-technical education, or training and upskilling combined with a non-technical profession. These women work in the ICT area of a non-tech profession in the management, design, programming, and implementation of new technology.

Interviews lasted around one hour and followed an interview guide with a professional-life history structure, including questions about family, education, occupational history, experiences of hierarchies and gender at work, career drivers, barriers, and work-family arrangements. Although interviewees also reflected on family roles and responsibilities apart from motherhood, it was mainly parenthood-related topics that triggered women to share their experiences of combining work and family. In this article, we focus on the narratives of women who explicitly reflected on how work and career development are entangled with family life, which involved care for children.

This study gained ethical approval from the Norwegian Centre for Research Data and followed their rules for data security. All informants are anonymous. Parenthesis following quotes indicate the participant's approximate age.

\section{Analytical framework}

The interviews were designed using the professional life history approach, and thus, our interviewees spoke about their work, careers, and personal lives. We considered the interview material to be narratives and analysed it using a narrative analysis approach. Narrative analysis, as Freeman (2015: 24) stresses, focuses on how people make sense of their experiences by constructing 'a coherent life out of the chaos of experience'. Narrative analysis takes the story as an object of interpretation. Thus, we attempted to understand women's experiences combining work and family life by asking why a narrative about family occurred during the part of our interview that focused on career. As Earthy and Cronin (2008: 8) explain, 'a narrative approach will take account of both the content and the form of the interviewee's account' by considering the way in which an interviewee narrates an experience.

A narrative about family often arose when we asked about the barriers our interviewees faced in career development or support for career development. By questioning why they spoke about their families in the context of their career in this particular way and at this particular point, we discovered the two leading ways women speak about how they combine ICT work and family life, which are outlined in the following section. Then, we compare the accounts to shed light on underlying gender structures and norms, while asking what the key factors affecting women's experiences of combining ICT work and family are.

\section{FINDINGS}

The fact that women in ICT work longer hours than women in many other occupations (EIGE, 2018), as they try to fit into a male-dominated and greedy work style, suggests that women in ICT struggle reconciling work and family. In this section, we introduce two narratives shared by our interviewees. The first narrative was shared by full-time working women who, even sometimes with support from their spouse and relatives, still had a feeling of having opted out. This feeling was expressed through the rhetoric of choice in relation to care responsibilities. The second narrative was shared by women who work more than standard full-time hours and receive spousal support. This narrative emphasises the privileges that enable women to pursue careers and have less care responsibilities.

\section{When full-time work equals opting out of career development}

About two thirds of the women explicitly pointed to family when asked about barriers to their career: 'The family, but... I have chosen that myself, so it is not something I am bitter about' (early 40s). These women all had between one and four young children and also worked full-time. Typically, when family or children were put forward as a barrier, interviewees immediately talked about this as a voluntary and a conscious choice:

Establishing a family, managing that, you could call it a barrier, but it was also a choice. It was completely voluntary. (late 30s)

Sørensen (2017) identified the discourse of the 'good mother', one who works part-time, as implicit in the opting out traceable in national statistics. However, different from this discourse and a home-centred narrative (Hakim, 2006), our women were in full-time work but still described a feeling of 'opting out':

I turn down travelling because I am away so much already. So, I avoided most of the travelling I could have done. (40s)

They were aware that they lost opportunities when deciding to have children:

The fact that I have chosen to have four children means that I cannot just take any job. That has to do with priorities. It was wanted and conscious. I could have chosen or prioritised differently. (40s) 
Every time you have a child... I've never been promoted or gotten a pay raise when I've been on [maternity] leave (...) So, you stagnate a bit. (30s)

Indeed, as they presupposed a balance between work and life in their career development (Rottenberg, 2018), our interviewees calculated what their career might have been if they had 'chosen' differently:

I could have prioritised having fewer children and aimed for a higher position. I think I could have had that if I wanted, but I made a different choice. (40s).

When the male-dominated work culture of ICT intersects with the gender hierarchies in the fields of research, development, and innovation (EIGE, 2020), even women with full-time work experience are punished, careerwise:

If I had other priorities, I could have been a professor. If you want to climb, you have to work more than a hundred percent. I refrain from many things because I have a family and want to be with them, and that prevents me from climbing in the system. (40s)

Although this narrative is reminiscent of the 'good mother' or other, home-centred narratives (Hakim, 2006; Sørensen, 2017), these women were holding full-time work in ICT while speaking to the fact that they prioritise family over work. Interviewees had not only foregone work activities, such as travelling, but also postponed careerdeveloping training. For instance, five of our interviewees had left behind their desires to obtain a $\mathrm{PhD}$. These women's version of work-life 'balance', however, disguises the cost of prioritising family over career-driving activities; costs that could have notable and long-term consequences on their careers. However, such costs are not visible in statistics, unlike the part-time working of 'good mothers' in Sørensen's study (2017).

Our interviewees' feeling of opting out did not stem from working life or the dual-earner model. It was not work, but their careers that they put on hold for children, and this hold is temporary:

I have three kids now and I don't think I will have more, so now it is a different situation (...) It is very exciting to be able to look forward to career possibilities. (30s)

Participants justified their feeling of opting out by pointing to family and children as a choice, an explanation that reproduces gender norms associating women with childcare responsibilities. The rhetoric of 'choice' reflects the gender practices of the two-track parenthood model, where women take more care-responsibilities, and contributes to covering up the feeling of opting out. Thus, our findings support Sørensen's suggestion that the rhetoric of choice might reproduce traditional gender roles by defining motherhood according to a maternal presence in the family (Sørensen, 2017).

Furthermore, the co-production of work and family - evident in our interviewees' claims of prioritising family while engaged in full-time work - indicates that working 'only' full-time is seen as limiting to career development. This resonates with research showing that women in ICT feel the need to adopt a male style and work long hours (Watts, 2009), which also indicates a greedy work culture with intense achievement targets, and expectations of availability and working time (Brandth and Kvande, 2005; Egeland and Bergene 2012).

\section{Career mothers needing supporters with predictable working hours}

In the second narrative, women also talked about their work in relation to care responsibilities; however, they described a situation in which they had less care-responsibility for family and children. Like Sørensen's (2017) 'failing (career) mothers', these women may risk being perceived as prioritising career and failing at motherhood. However, in their (nonjudgmental) narratives (different from the judgmental tendency in the media discourse Sørensen analyses), women described how supporters took care of their childcare tasks.

Unlike Sørensen's 'exceptional mothers' who buy support from cleaners and au pairs, only one of the women in our study mentioned domestic help. Instead, their male partners took on the main childcare responsibilities:

Because I'm commuting, it is him who picks up and drops off at school and kindergarten every day. (...) Even the one day a week that I'm at home, he still picks them up and drops them off. (30s)

Furthermore, participants did not speak of pursuing a career while having children as a choice, but rather a privilege entangled with and dependent on a supportive partner:

My husband was very good at staying home. He has helped out there, and he is still the one making dinner at home. He has taken that over more and more, and now I don't even know what we're having for dinner. (50s) 
Among our interviewees, there were also examples of dual-career couples who both had greedy careers (Hakim, 2006). In these cases, support from other close relatives was needed to help supplement the care for family and children, such as the women's parents:

My husband is travelling and away a lot as well, and then we have my mother and father. (...) My father, he is still working, but he is working from home. He is looking after them [the children] a lot. (40s)

This example involves two generations of dual-career couples and a grandfather solving the challenges, thanks to work arrangements that make him available for the children. However, this example stands apart from Pederson and Egeland's study on Norwegian parents' everyday life (2020) that shows how grandparents contribute by helping to unburden families' everyday lives in relation to care, but here the grandparents contribute by making an intensive work culture possible.

Pedersen and Egeland (2020) also argue that the Norwegian ideal of parenthood involves equal parenting and time spent with children in evenings and weekends, even though women do more household and administrate care responsibilities. Nevertheless, combining work and care responsibilities to some degree depends on working hours. Parents with flexible working hours can better facilitate care responsibilities in everyday life (Pedersen and Egeland, 2020: 20). Among our interviewees, aside from one case of a male partner who became a stay-at-home-dad to support the woman's career, it was not the women's flexible working practices that helped, but the opposite: their partners had stable work positions with flexible and predictable hours and little or no work-related travel. This is what made the women's greedy work possible.

My husband has not changed his job much. He has not had jobs where he had to travel. If he also had a job where he had to travel a lot, things would have been much more difficult. He was always at home. (50s)

As public childcare services do not cover the amount of care women who work over full-time hours require, they need a close supporter to step in where public childcare ends and, in this way, help stabilise their work practices. For our participants, it was not only the partners with flexible working hours who dropped off and picked up children from school that solved work and care conflicts, it was also the husbands who did not travel much and were available out of office hours, and the fathers who took extra leave. The women interviewed here identified their partners' flexible working hours as a support, so long as work remained within and did not exceed either standard work times or number of hours. If we consider two-track parenthood as the main gender norm reconciling work-life balance in Norway, even with equally shared parenting as the ideal, the mentioned privileges enable both a negotiation for re-doing gender and, at the same time, the continuation of a two-track parenthood model. However, how gender norms are re-done here involves men taking more responsibility for children and family along the lines of the traditional female role. Thus, this also involves negotiating solutions and arrangements that challenge the hegemonic gender norms of men as the ideal worker (Hook, 2010).

\section{DISCUSSION}

A recognised challenge to work-life balance policies is that they often rely on a flexibility-of-work discourse which enables employees to adjust work according to family responsibilities (Singley and Hynes, 2005). However, flexible work practices may also have the opposite effect; indeed, some are seen as employer-friendly, rather than being supportive of employees (Fleetwood, 2007). Family-friendly policies providing a high level of work flexibility are recognised as increasing gender inequality in working life, as women mainly adopt the role of carer in the twotrack parenthood model (Ellingsæter, 2006; Hakim, 2006). While work-life policies take for granted that flexibility at work implies working less during office hours to spend time on family, the women in our study that spoke to this mostly described working more, with longer days and more travelling. Flexibility in greedy work cultures is not just a simple adjustment of work time and place; in such contexts, rather, flexibility institutes working more than full-time as the norm, which conflicts with family responsibilities even if women do not 'prioritise' family.

This does not only leave the struggle of reconciling work and family responsibilities to the individual (Gregory and Milner, 2009), but also turns the issue of intensive and greedy work cultures into an issue solved in the private sphere. Through the rhetoric of choice, the work-life balance discourse frames greedy work cultures as a problem of prioritising children, even when women work full-time. Therefore, the two-track parenthood model is regendered while the greedy work style that Padavic et al. (2019) identify as the main obstacle to gender inequality in working life (especially in ICT work), goes unchallenged.

Our study challenges the traditional two-track parenthood model that gives priority to the father's career (Halrynjo and Lyng, 2010; Sørensen, 2017), as our participants' male partners were instead taking on roles traditionally associated with women. Both stay-at-home dads and fathers with more flexible and predictable work 
hours were key to solving the work-life time squeeze, giving priority to women's careers. As has been shown regarding dual-career couples, women who pursue a career need private supporters (Metz-Goeckel, 2018). In addition, as the second narrative may suggest, changes in how heterosexual couples negotiate work and family allow women to develop a career. However, as Pedersen and Egeland (2020) argue, flexible hours in normal working time was a privilege for those who have undergone longer higher education.

The work-life balance discourse's focus on time management and choice seems too narrow to precisely capture women's negotiation of work and family. This becomes evident in the mismatch between women's narratives of choosing or prioritising family over work, while still engaged in full-time work. As Biese and Choroszewicz (2019) point out, the issue of opting out has often been associated with women who leave the work force altogether. However, our participants' feeling of having to 'opt out' indicates that success in their work environments requires more than full-time commitment. Having said this, the women in our study also did not imagine this opting out in the way that the term is often taken, in definitions of women who prioritise family (Hakim, 2006; Quesenberry et al., 2006; Sørensen, 2017). Also, in contrast to the adaptive category Hakim defines, these women tended to see the child-period as an intermezzo in their career, rather than a reason to take on part-time work.

While part-time work indicates gender inequality (Statistics Norway, 2017), our interviewees' full-time participation could be interpreted as a success of policies aimed at keeping women in the workforce. Simultaneously, however, the feeling of opting out that they describe is critical, as it is not visible in national statistics but will continue to produce vertical gender segregation; opportunities that women let pass by, because of this, are likely to slow their career trajectories. In a field like ICT, where women are a minority, this has unfortunate consequences.

Hakim suggests that part-time working mothers are in danger of losing the competition against full-time workers, due to the advantageous amount of knowledge and experience full-time workers obtain (2006). However, it seems Hakim's dividing line between part-time and full-time work is too optimistic for women ICT experts. Instead, our findings support Watts' (2009) study, which highlights that women feel long working hours are required to develop a successful career in male-dominated fields.

\section{CONCLUSION}

Our study illustrates that even in Norway, which boasts some of the world's most family-friendly policies (Seierstad and Kirton, 2015), the available public childcare and work-life balance solutions are not sufficient to support women in greedy work cultures, such as ICT. We need to look beyond the discourse of flexible working hours to truly understand what women's experiences of prioritising family in a greedy work culture really entail. Some of our interviewees claimed that they prioritise family over work, yet they acted more along the lines of adaptive or work-centred participants in other studies (Hakim, 2006; Sørensen, 2017). Thus, it can be seen that dividing women into work-or-family categories does not fully capture the experiences of women ICT experts and masks the 'opting out' of women working full-time in cultures that require continuous upskilling and long hours (EIGE, 2020).

The work-life balance policies, making time management and flexibility central, falls short in fields that are both male-dominated and vertically gender segregated. From a work-life balance policy perspective, using flexible working condition to keep women in paid work has been a success. Our findings also support a growing acceptance of women developing their careers. However, most women experience a requirement to work in the pattern of men's career development to achieve this. Our study suggests an urgent need to reorient work-life discussions more towards career-life policies and solutions that acknowledge the challenges of greedy work styles. Our findings indicate that balance is an illusion in intensive and greedy work cultures. Rather, women with full-time work still describe prioritising family and therefore feel that they are opting out while women who work more than full-time rely on the partner's work conditions for making intensive work possible.

Our informants' voices were united in describing how their career development requires private support. As one said: 'If it had been only me, it would not have worked out.' Indeed, a male partner's predictable and less greedy work pattern, not work-life balance policies targeting women, is the main factor enabling women to combine work and family responsibilities in ICT research, development, and innovation.

We recognise that work-life balance policies have not only aimed at keeping women in paid work, but also have men take more responsibility in the home. This is not easy to solve with legislation, as it requires attitudes towards traditional gender patterns of work-family arrangements to change, which this study's participants suggest is in part happening. However, the negotiation necessary to achieve this is left to individuals, remaining an issue of the private sphere. 


\section{REFERENCES}

Acker, J. (1990). Hierarchies, Jobs, Bodies: A Theory of Gendered Organizations. Gender \& Society, 4, 139-158. https://doi.org/10.1177/089124390004002002

Bailey, M. and Riley, S. (2018). 2018 Women in Tecb: Unconscious bias, parity, and the path forward. Woman in Technology International. Available at: https:// witi.com/IDC-2018-Women-in-Tech.pdf. (Accessed 15 January 2021).

Biese, I. and Choroszewicz, M. (2019). Opting Out: Professional Women Develop Reflexive Agency. Equality, Diversity and Inclusion: An International Journal, 38(6), 619-633. https://doi.org/10.1108/EDI-06-2018-0097

Bø, T. P., Kitterød, R. H., Køber, T., Nerland, S. M. and Skoglund, T. (2008). Arbeidstiden-monstre og utviklingstrekk (Working Time Patterns and Development). Oslo-Kongsvinger: Rapport 2008/12. Oslo: Statistisk sentralbyrå (Statistics Norway).

Brandth, B. and Kvande, E. (2005). Fedres valgfrihet og arbeidslivets tidskulturer (Fathers' freedom of choice and the time cultures of working life). Tidsskrift for samfunnsforskning, 1, 35-54. https:// doi.org/10.18261/ISSN1504291X-2005-01-02

Chung, H. and Van der Lippe, T. (2018). Flexible Working, Work-Life Balance, and Gender Equality: Introduction. Social Indicators Research, 151, 365-381. https:// doi.org/10.1007/s11205-018-2025-x

Cockburn, C. (1992). The Circuit of Technology: Gender, Identity and Power, in R. Silverstone and E. Hirsch (eds), Consuming Technologies: Media and information in domestic spaces (pp. 32-47). London: Routledge. https://doi.org/10.4324/9780203401491_chapter_2

Consalvo, M. (2008). Crunched by Passion: Women Game Developers and Workplace Challenges, in Y. B. Kafai, C. Heeter, J. Denner and J. Y. Sun (eds), Beyond Barbie and Mortal Kombat: New perspectives on gender and gaming (pp. 177-192). Cambridge, MA: MIT Press.

Corneliussen, H. G. (2011). Gender-Technology Relations: Exploring stability and change. Basingstoke: Palgrave Macmillan.

Corneliussen, H. G. (2014). Making the Invisible Become Visible: Recognizing Women's Relationship with Technology. International Journal of Gender, Science and Technology, 6(2), 209-222.

Danielsen, H., Larsen, E. and Owesen, I. W. (2013). Norsk likestillingshistorie 1814-2013 (Norwegian Gender Equality History). Oslo: Fagbokforlaget.

Earthy, S. and Cronin, A. (2008). Narrative Analysis, in N. Gilbert. (ed), Researching Social Life, 3rd Edition. London: Sage.

EIGE. (2018). Women and Men in ICT: A chance for better work-life balance - Research note. Luxembourg: EIGE (European Institute for Gender Equality, Publications Office of the European Union).

EIGE. (2020). Gender Equality Index 2020: Digitalisation and the future of work. Luxembourg: EIGE (European Institute for Gender Equality, Publications Office of the European Union).

Ellingsæter, A. L. (2002). Postindustrielle tidskontrakter. Fra tidsdisiplin til tidssuverenitet? (Post-industrial time contracts)., in A. L. Ellingsæter and Jorun Solheim (eds), Den usynlige haind? Kjonnsmakt og moderne arbeidsliv. Maktog demokratiutredningen 1998-2003. Oslo: Gyldendal Akademisk Forlag.

Ellingsæter, A. L. (2006). Nordiske permisjoner for foreldre-et columbi egg? (Nordic Parental Leave - a Columbus Egg?). Tidsskrift for velferdsforskning, 9(2), 73-87.

Ellingsæter, A. L. and Leira, A. (2006). Politicising Parenthood in Scandinavia: Gender relations in welfare states. Bristol: Policy Press. https://doi.org/10.2307/j.ctt9qgtw3

Felstead, A., Jewson, N., Phizacklea, A. and Walters, S. (2002). Opportunities to Work at Home in the Context of Work-Life Balance. Human Resource Management Journal, 12(1), 54-76. https://doi.org/10.1111/j.17488583.2002.tb00057.x

Fleetwood, S. (2007). Why Work-Life Balance Now? The International Journal of Human Resource Management, 18(3), 387-400. https://doi.org/10.1080/09585190601167441

Franzway, S. (2001). Sexual Politics and Greedy Institutions. Annandale: Pluto Press Australia.

Freeman, M. (2015). Narrative as a Mode of Understanding, in A. De Fina and A. Georgakopoulou (eds), The Handbook of Narrative Analysis (pp. 19-37). Hoboken, NJ: John Wiley \& Sons, Inc. https://doi.org/10.1002/9781118458204.ch1

Gherardi, S. (1994). The Gender We Think, The Gender We Do in Our Everyday Organizational Lives. Human Relations, 47(6), 591-610. https: / / doi.org/10.1177/001872679404700602

Gram, K. H. (2019). The Paternity Leave is Still Popular. SSB. Available at: https://www.ssb.no/en/befolkning/ artikler-og-publikasjoner/the-paternity-leave-is-still-popular. (Accessed 18 December 2020).

Gregory, A. and Milner, S. (2009). Work-Life Balance: A Matter of Choice? Gender, Work \& Organization, 16(1), 113. https://doi.org/10.1111/j.1468-0432.2008.00429.x

Hakim, C. (2006). Women, Careers, and Work-Life Preferences. British Journal of Guidance \& Counselling, 34(3), 279294. https://doi.org/10.1080/03069880600769118 
Halrynjo, S. and Lyng, S. T. (2010). Fars forkjørsrett - mors vikeplikt? Karriere, kjønn og omsorgsansvar i eliteprofesjoner (Father's right of way - mother's duty to give way? Career, gender and caring responsibilities in elite professions). Tidsskrift for samfunnsforskning, 51(02), 249-280. https://doi.org/10.18261/ISSN1504291X-2010-02-03

Halrynjo, S. and Teigen, M. (eds). (2016). Ulik likestilling i arbeidslivet (Unequal Equality in Working Life). Oslo: Gyldendal Akademisk.

Håpnes, T. and Rasmussen, B. (2007). Familievennlige kunnskapsbedrifter: Fleksible versus byråkratiske organisasjonsformer? (Family Friendly Knowledge Organizations), in E. Kvande and B. Rasmussen (eds), Arbeidslivets klemmer. Paradokser i det nye arbeidslivet (146-167). Bergen: Fagbokforlaget.

Hays, S. (1996). The Cultural Contradictions of Motherbood. New Haven: Yale University Press.

Hernes, H. M. (1987). Welfare State and Women Power: Essays in state feminism. Oslo: Norwegian University Press.

Hirschauer, S. (2001). Das Vergessen des Geschlechts. Zur Praxeologie einer Kategorie sozialer Ordnung, in B. Heintz (ed), Geschlechtersoziologie (Vol. 41) (pp. 208-235), Wiesbaden: Kçlner Zeitschrift für Soziologie und Sozialpsychologie, Sonderheft.

Hook, J. L. (2010). Gender Inequality in the Welfare State: Sex Segregation in Housework, 1965-2003. American Journal of Sociology, 115(5), 1480-1523. https:// doi.org/10.1086/651384

Johnsen, J. V. and Løken, K. V. (2016). Likestilling og framtidens familiepolitikek (Gender equality and the family policy of future). Available at: https://www.uib.no/sites/w3.uib.no/files/attachments/familiepolitikk-og-arbeidsliv_feb_11_2016-v2.pdf.

Kelan, E. K. (2010). Gender Logic and (Un)Doing Gender at Work. Gender, Work \& Organization, 17(2), 174-194. https://doi.org/10.1111/j.1468-0432.2009.00459.x

Kitterød, R. H. and Halrynjo, S. (2019). Mer likestilling med fedrekvote? Naturlige eksperimenter i norsk kontekst (More equality with father quota? Natural experiments in the Norwegian context). Tidsskrift for kjonnsforskning, 43(2), 71-89. https:// doi.org/10.18261/issn.1891-1781-2019-02-02

Kitterød, R. H. and Rønsen, M. (2012). Non-Traditional Dual Earners in Norway: When Does She Work at Least as Much as He? Work, Employment and Society, 26(4), 657-675. https://doi.org/10.1177/0950017012445090

Lewis, S., Gambles, R. and Rapoport, R. (2007). The Constraints of a 'Work-Life Balance'approach: An International Perspective. The International Journal of Human Resource Management, 18(3), 360-373. https://doi.org/10.1080/09585190601165577

Mauno, S., Minkkinen, J. Tsupari, H., Huhtala, M. and Feldt, T. (2019). Do Older Employees Suffer More from Work Intensification and Other Intensified Job Demands? Evidence From Upper White-Collar Workers. Scandinavian Journal of Work and Organizational Psychology, 4(1), 1-13. http://doi.org/10.16993/sjwop.60

McRobbie, A. (2009). The Aftermath of Feminism: Gender, culture and social change. London: Sage.

Melby, K. and Carlsson Wetterberg, C. (2009). Gender Equality and Welfare Politics in Scandinavia: The limits of political ambition? Bristol: Policy Press. https://doi.org/10.1332/policypress/9781847424655.001.0001

Metz-Goeckel, S. H. (2018). The Perfect Course of Life (CV) and Double-Career Couples in Science. International Journal of Gender, Science and Technology, 10(1), 7-23.

Misa, T. J. (Ed.) (2010). Gender Codes: Why women are leaving computing. Hoboken, New Jersey: IEEE Computer Society and John Wiley \& Sons, Inc. https://doi.org/10.1002/9780470619926

Nentwich, J. C. and Kelan, E. K. (2014). Towards a Topology of 'Doing Gender': An Analysis of Empirical Research and its Challenges. Gender, Work and Organization, 21(2), 121-134. https://doi.org/10.1111/gwao.12025

Niemistö, C., Hearn, J., Karjalainen, M. and Touri, A. (2020). Interrogating Silent Privileges Across the Work-Life Boundaries and Careers of High-Intensity Knowledge Professionals. Qualitative Research in Organizations of Management: An International Journal, 15(4), 503-522. https://doi.org/10.1108/QROM-06-2019-1775

Nilsen, A. and Skarsbø, A. M. (2009). Familie, jobb og karriere - noen dilemmaer for likestilling, in K. Christensen and L. J. Syltevik (eds), Kvinners arbeid (pp. 9-28). Oslo: Unipub.

OECD. (2004). Babies and Bosses - Reconciling Work and Family Life. Canada, Finland, Sweden, UK, Paris. Available at: https://www.oecd.org/els/family/babiesandbosses-reconcilingworkandfamilylifevol4canadafinland swedenandtheunitedkingdom.htm. (Accessed 13 April 2021).

Padavic, I., Ely, R. J. and Reid, E. M. (2019). Explaining the Persistence of Gender Inequality: The Work-Family Narrative as a Social Defense Against the 24/7 Work Culture. Administrative Science Quarterly, 65(1), 61-111. https://doi.org/10.1177/0001839219832310

Pedersen, E. and Egeland, C. (2020). Hverdagsliv og familieliv $i$ Norge i 2020 (Everyday life and family life in Norway in 2020). Oslo: Work Research Institute (AFI). Oslo Metropolitan University.

Peetz, D. (2006). Brave New Workplace: How individual contracts are changing our jobs. Crows Nest: Allen and Unwin. 
Quesenberry, J. L., Trauth, E. M. and Morgan, A. J. (2006). Understanding the 'Mommy Tracks': A Framework for Analyzing Work-Family Balance in the IT Workforce. Information Resources Management Journal (IRMJ), 19(2), 37-53. https://doi.org/10.4018/irmj.2006040103

Richardson, H. and Bennetts, D. (2007). Work-Life Imbalance of IT Workers in the Internet Age, in P. Yang and S. Huff (eds), Managing IT Professionals in the Internet Age (pp. 37-87). Hershey, PA: IGI Global. https://doi.org/10.4018/978-1-59140-917-5.ch003

Rottenberg, G. (2018). The Rise of Neoliberal Feminism. Oxford Scholarship Online. https://doi.org/10.1093/oso/ 9780190901226.001 .0001

Rudlende, L. and Bryghaug, R. (2017). Familiens bruk av foreldrepenger etter fødsel. Oslo: NAV. Available at: https://www.nav.no/no/nav-og-samfunn/statistikk/familie-statistikk/foreldrepenger. (Accessed 23 January 2021).

Samordna opptak. (2018). The Norvegian Universities and Colleges Admission Service (Samordna opptak). Available at: https://www.samordnaopptak.no/info/om/sokertall/. (Accessed 13 April 2021).

Seierstad, C. and Kirton, G. (2015). Having it all? Women in High Commitment Careers and Work-Life Balance in Norway. Gender, Work \& Organization, 22(4), 390-404. https://doi.org/10.1111/gwao.12099

Simonsen, M. and Corneliussen, H. G. (2020). What can Statistics Tell About the Gender Divide in ICT? Tracing Men and Women's Participation in the ICT Sector Through Numbers, in D. Kreps, T. Komukai, G. TV and K. Ishii (eds), Human-Centric Computing in a Data Driven Society (pp. 379-397). New York: Springer. https://doi.org/10.1007/978-3-030-62803-1_30

Singley, S. G. and Hynes, K. (2005). Transitions to Parenthood: Work-Family Policies, Gender, and the Couple Context. Gender \& Society, 19(3), 376-397. https:/ / doi.org/10.1177/0891243204271515

Singstad, B. N. (2011). Det «overbestemte» livet?: Balansering av arbeid og familieliv i IT-bransjen i Norge, Malaysia og California (The 'over-determined' life?: Balancing work and family life in the IT industry in Norway, Malaysia and California). Trondheim: Norges teknisk-naturvitenskapelige universitet, Det humanistiske fakultet.

Sinnes, A. T. and Løken, M. (2014). Gendered Education in a Gendered World: Looking Beyond Cosmetic Solutions to the Gender Gap in Science. Cultural Studies of Science Education, 9(2), 343-364. https://doi.org/10.1007/s11422-012-9433-z

Sørensen, K. H., Faulkner, W. and Rommes, E. (2011). Technologies of Inclusion. Gender in the information society. Trondheim: Tapir Academic Press.

Sørensen, S. Ø. (2017). The Performativity of Choice: Postfeminist Perspectives on Work-Life Balance. Gender, Work \& Organization, 24(3), 297-313. https://doi.org/10.1111/gwao.12163

Statistics Norway. (2017). Gender-divided labour market. Available at: https://www.ssb.no/en/befolkning/ artikler-og-publikasjoner/gender-divided-labour-market. (Accessed 6 May 2021).

Statistics Norway. (2018). Dette er kvinner og menn $i$ Norge (This is Women and Men in Norway): Statistisk sentralbyrå. Available at: https://www.ssb.no/befolkning/artikler-og-publikasjoner/dette-er-kvinner-og-menn-i-norge2018. (Accessed 13 April 2021).

Stefansen, K. and Aarseth, H. (2011). Enriching Intimacy: The Role of the Emotional in the 'Resourcing' of Middle-Class Children. British Journal of Sociology of Education, 32(3), 389-405. https://doi.org/10.1080/ 01425692.2011 .559340

Wajcman, J. (2004). TechnoFeminism. Cambridge: Polity Press.

Watts, J. H. (2009). Allowed into a Man's World. Meanings of Work-Life Balance: Perspectives of Women Civil Engineers as 'Minority'workers in Construction. Gender, Work \& Organization, 16(1), 37-57. https://doi.org/10.1111/j.1468-0432.2007.00352.x

West, C. and Zimmerman, D. H. (1987). Doing Gender. Gender \& Society, 1(2), 125-151. https://doi.org/10.1177/0891243287001002002

Williams, J. C. (2000). Unbending Gender. Oxford: Oxford University Press.

Zerwas, C. S. (2019). Work-Life Balance and Women's Entrepreneurship: An exploration of influencing factors. Switzerland Springer Nature. https:/ / doi.org/10.1007/978-3-030-29804-3

Citation: Seddighi, G. and Corneliussen, H. G. (2021). The Illusion of Balance: Women in ICT Working FullTime and Still Having a Feeling of Opting Out. Feminist Encounters: A Journal of Critical Studies in Culture and Politics, 5(2), 26. https://doi.org/10.20897/femenc/11163

Copyright (C) 2021 by Author/s and Licensed by Lectito BV, Netherlands. This is an open access article distributed under the Creative Commons Attribution License which permits unrestricted use, distribution, and reproduction in any medium, provided the original work is properly cited. 